\title{
Damage to the reefs of Port Honduras Marine Reserve, Belize, during the 28 May 2009 earthquake
}

Received: 1 July 2009/Accepted: 7 August 2009/Published online: 26 August 2009

(C) Springer-Verlag 2009

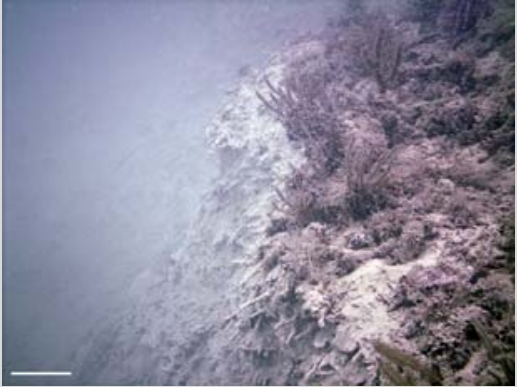

Fig. 1 Newly formed escarpment created by the reef edge sliding down the wall at Boiling Patch. Scale bar $=0.50 \mathrm{~m}$

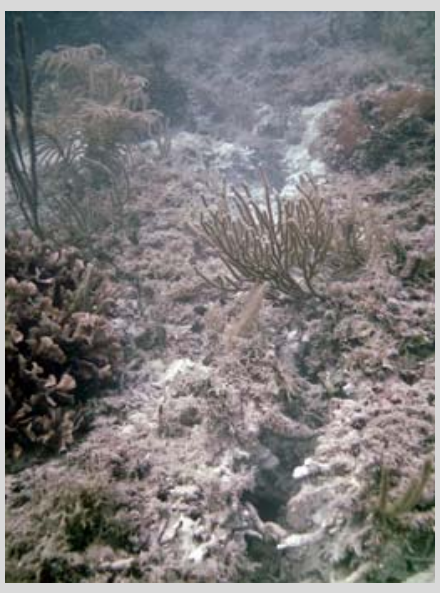

Fig. 2 Crack ( $0.12 \mathrm{~m}$ wide) running through the reef at Boiling Patch

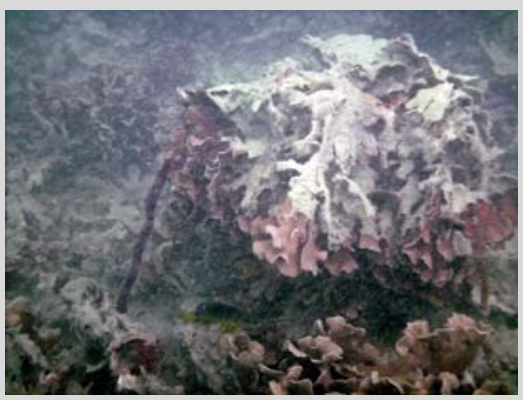

Fig. 3 Overturned colony of Agaricia tenuifolia $(0.80 \mathrm{~m}$ diameter $)$

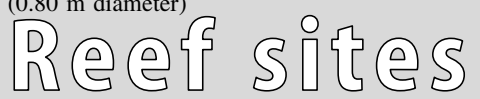

On 28 May 2009, a 7.3 magnitude earthquake occurred at a depth of $10 \mathrm{~km}$ along the boundary between the North American and Caribbean plates, $125 \mathrm{~km}$ NNE of La Ceiba, Honduras (USGS 2009). Tremors were felt in many neighbouring countries including Belize, El Salvador and Guatemala. The last major earthquake to occur in the region was a 6.6 magnitude quake on 11 July 1999 (MIDAS 2009). The Port Honduras Marine Reserve $\left(414 \mathrm{~km}^{2}\right)$ is in the Gulf of Honduras, 270 $\mathrm{km}$ WSW of the earthquake epicentre. Underwater visual surveys were conducted on SCUBA at 15 sites after the earthquake, covering an area of $\sim 5,000 \mathrm{~m}^{2} \mathrm{site}^{-1}$. Of the sites surveyed, seven showed no damage, four showed minimal damage and four were heavily impacted by the earthquake.

On the shallow inner reefs ( $<5 \mathrm{~m}$ deep), located on relatively flat, sandy areas (Heyman and Kjerfve 2001), minimal damage was observed. However, the reefs on the outer banks $(\sim 15 \mathrm{~m})$ and at the Snake Cayes $(7-10 \mathrm{~m})$ (Heyman and Kjerfve 2001) suffered significant damage, with two sites, in particular, badly affected. At Boiling Patch ( 10 m deep) and South Snake Bank ( 13 m deep), a $160 \mathrm{~m}$ and a $30 \mathrm{~m}$ long stretch of reef edge, respectively, had broken away from the main reef and slipped down the wall (Fig. 1). Large areas of hard-coral-dominated habitat, renowned for high densities of Caribbean spiny lobster, were destroyed. In addition, a number of large cracks ( $\sim 10 \mathrm{~m}$ long, $0.12 \mathrm{~m}$ wide and up to $0.25 \mathrm{~m}$ deep) had opened up across the reef at both Boiling Patch (Fig. 2) and South Snake Bank. At South Snake Bank, over 200 coral colonies and barrel sponges had been overturned or broken apart (Fig. 3). The fragile Agaricia sp. corals were more susceptible to damage with many colonies breaking apart or falling over. Many large colonies of Montastraea annularis lost columns from their outer edges.

Acknowledgments TIDE thanks The OAK Foundation, The Summit Foundation and The Nature Conservancy for funding.

\section{References}

Heyman WD, Kjerfve B (2001) The Gulf of Honduras. In: Seeliger U, Kjerfve B (eds) Coastal marine ecosystems of Latin America. Springer, Berlin, pp 360 MIDAS (2009) Significant Events, Middle America Seismograph Consortium. http://midas.upr.clu.edu/mds-recent.html

USGS (2009) Earthquake Report - 7.3 - offshore Honduras. United States Geological Survey. http://earthquake.usgs.gov/eqcenter/eqinthenews/2009/ us2009heak/

N. L. Foster $(\bowtie) \cdot$ M. Williams · S. Chan · C. Ramirez

Toledo Institute for Development and Environment (TIDE), 1 Mile San Antonio Road, Punta Gorda, Belize

e-mail: nicolalouise.foster@gmail.com

V. Vasquez

Fisheries Department, Government of Belize, Punta Gorda Office, Prince Street, Punta Gorda, Belize

Coral Reefs (2010) 29:19

DOI $10.1007 / \mathrm{s} 00338-009-0542-4$ 